\title{
0589. Pravastatin exerts opposite effects on splanchnic microcirculatory oxygenation during sham or septic conditions in an animal model of polymicrobial sepsis
}

\author{
C Beck, F Barthel, A Herminghaus, C Vollmer, I Bauer, O Picker \\ From ESICM LIVES 2014 \\ Barcelona, Spain. 27 September - 1 October 2014
}

\section{Introduction}

In addition to lipid-lowering effects HMG-CoA reductase inhibitors like pravastatin also modulate the microcirculation [1]. The exact mechanisms are yet unknown and results are heterogeneous, with both positive and negative effects on endothelial microvascular function $[2,3]$ being reported.

\section{Objectives}

The aim of this study was to evaluate the effects of pravastatin on the microcirculatory oxygenation of the colon in a rodent model of polymicrobial sepsis.

\section{Methods}

The data derive from a total of 40 experiments on rats studied with approval of the local animal care and use committee. Pravastatin $(0.2 \mathrm{mg} / \mathrm{kg})$ or $\mathrm{NaCl}$ were injected subcutaneously $18 \mathrm{~h}$ prior to sepsis induction (colon ascendens stent peritonitis) or sham operation. $24 \mathrm{~h}$ after induction of sepsis the animals were re-laparotomized under general anaesthesia and received ongoing fluid replacement and pressure-limited ventilation for $120 \mathrm{~min}$. Macrohemodynamic variables were recorded and microcirculatory oxygen supply $\left(\mu \mathrm{DO}_{2}\right)$ and post-capillary oxygen saturation $\left(\mu \mathrm{HbO}_{2}\right)$ of the colon were measured simultaneously via laser Doppler and tissue reflectance spectrophotometry, respectively. Data are presented as means \pm SD, 2-way ANOVA followed by Dunnett (vs. baseline) or Tukey (between groups).

University Hospital Duesseldorf, Department of Anaesthesiology, Duesseldorf, Germany

(c) 2014 Beck et al; licensee Springer. This is an Open Access article distributed under the terms of the Creative Commons Attribution License (http://creativecommons.org/licenses/by/2.0), which permits unrestricted use, distribution, and reproduction in any medium, provided the original work is properly cited.

\section{Results}

1.) In pravastatin pre-treated sham animals the microcirculatory oxygenation $\mu \mathrm{HbO}_{2}$ declined by $9.8 \pm 9.4 \%$ with no change in the $\mathrm{NaCl}$ group. Figure 1.

2.) During sepsis pravastatin pre-treatment ameliorated the deterioration of $\mu \mathrm{HbO}_{2}(-5.5 \pm 8.2 \%)$, compared to a significant decrease in the $\mathrm{NaCl}$ group $(-8.4 \pm 8.7 \%)$. Figure 2 .

3.) Macrohaemodynamic variables and microcirculatory oxygen supply of the colon did not differ between the groups.

\section{Conclusion}

Pravastatin has opposite effects on splanchnic microcirculatory oxygenation depending on septic or non-septic conditions. These effects are independent of the macrocirculation or microcirculatory oxygen supply.

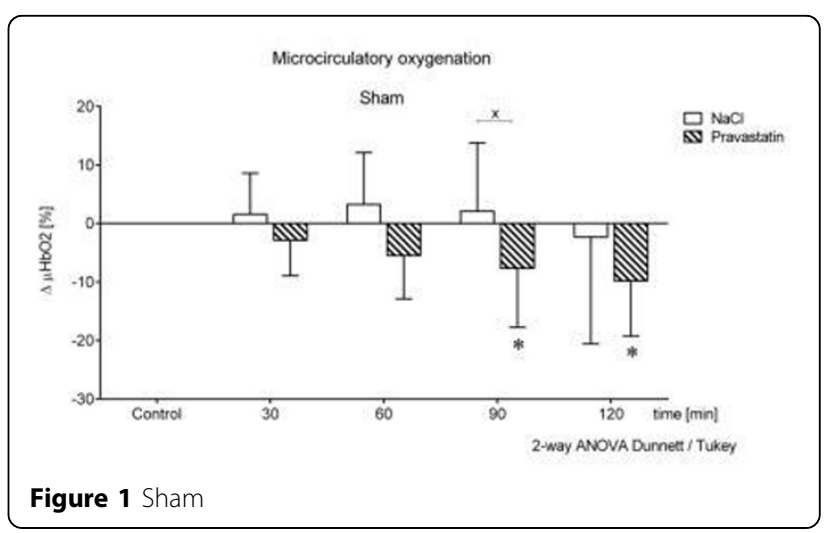




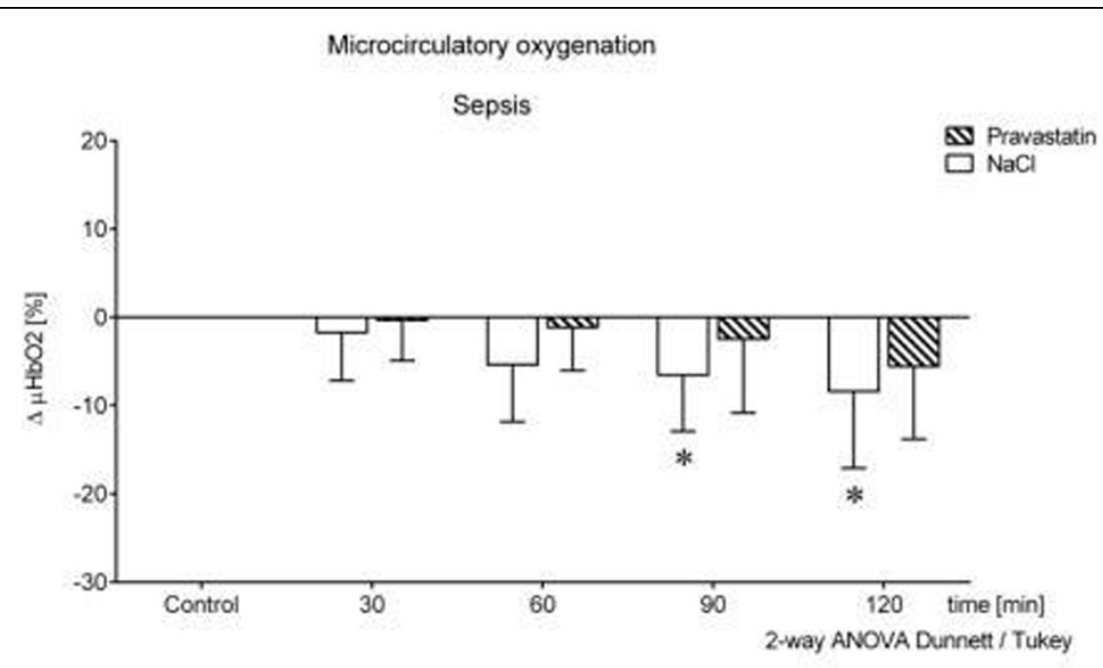

Figure 2 Sepsis

Published: 26 September 2014

\section{References}

1. McGown CC, Brookes $\mathrm{ZL}$ : Beneficial effects of statins on the microcirculation during sepsis: the role of nitric oxide. Br J Anaesth 2007, 98:163-175.

2. La Mura V, Pasarin M, Meireles CZ, Miquel R, Rodriguez-Vilarrupla A, Hide D, Gracia-Sancho J, Garcia-Pagan JC, Bosch J, Abraldes JG: Effects of simvastatin administration on rodents with lipopolysaccharide-induced liver microvascular dysfunction. Hepatology 2013, 57:1172-1181.

3. Tehrani S, Mobarrez F, Lins PE, Adamson U, Wallen HN, Jorneskog G: Impaired endothelium-dependent skin microvascular function during high-dose atorvastatin treatment in patients with type 1 diabetes. Diabetes \& vascular disease research 2013, 10:483-488.

doi:10.1186/2197-425X-2-S1-P34

Cite this article as: Beck et al:: 0589. Pravastatin exerts opposite effects on splanchnic microcirculatory oxygenation during sham or septic conditions in an animal model of polymicrobial sepsis. Intensive Care Medicine Experimental 2014 2(Suppl 1):P34.

\section{Submit your manuscript to a SpringerOpen ${ }^{\circ}$ journal and benefit from:}

- Convenient online submission

- Rigorous peer review

- Immediate publication on acceptance

- Open access: articles freely available online

- High visibility within the field

- Retaining the copyright to your article

Submit your next manuscript at $>$ springeropen.com 